\title{
Volatile compounds and some physico-chemical properties of pastırma produced with different nitrate levels
}

\author{
Ahmet Akköse ${ }^{1}$, Nazen Ünal', Barış Yalınkılıç ${ }^{2}$, Güzin Kaban $^{1, *}$, and Mükerrem Kaya ${ }^{1}$
}

* Corresponding Author: Güzin Kaban Tel: +90-442-2312425, Fax: +90-442-2360958,

E-mail: gkaban@atauni.edu.tr

'Department of Food Engineering, Faculty of Agriculture, Atatürk University, Erzurum 25240, Turkey

${ }^{2}$ Department of Food Engineering, Faculty of

Engineering, I ğdır University, I ğdır 76002, Turkey

Submitted Jul 6, 2016; Revised Oct 3, 2016; Accepted Dec 10, 2016
Objective: The aim of the study was to evaluate the effects of different nitrate levels $(150,300$, 450 , and 600 ppm $\mathrm{KNO}_{3}$ ) on the volatile compounds and some other properties of pastirma. Methods: Pastirma samples were produced under the controlled condition and analyses of volatile compounds, and thiobarbituric acid reactive substances (TBARS) as an indicator of lipid oxidation, non-protein nitrogenous matter content as an indicator of proteolysis, color and residual nitrite were carried out on the final product. The profile of volatile compounds of pastirma samples was analyzed by gas chromatography/mass spectrometry using a solid phase microextraction.

Results: Nitrate level had a significant effect on $\mathrm{pH}$ value $(\mathrm{p}<0.05)$ and a very significant effect on TBARS value $(\mathrm{p}<0.01)$. No significant differences were determined in terms of $\mathrm{a}_{\mathrm{w}}$ value, non-protein nitrogenous substance content, color and residual nitrite between pastırma groups produced by using different nitrate levels. Nitrate level had a significant $(\mathrm{p}<0.05)$ or a very significant $(\mathrm{p}<0.01)$ effect on some volatile compounds. It was determined that the amounts and counts of volatile compounds were lower in the 450 and especially 600 ppm nitrate levels than 150 and 300 ppm nitrate levels $(\mathrm{p}<0.05)$. While the use of $600 \mathrm{ppm}$ nitrate did not cause an increase in residual nitrite levels, the use of $150 \mathrm{ppm}$ nitrate did not negatively affect the color of pastırma. However, the levels of volatile compounds decreased with an increasing level of nitrate.

Conclusion: The use of 600 ppm nitrate is not a risk in terms of residual nitrite in pastırma produced under controlled condition, however, this level is not suitable due to decrease in the amount of volatile compounds.

Keywords: Pastırma; Nitrate; Thiobarbituric Acid Reactive Substances (TBARS); Non-protein Nitrogenous Matter (NPN-M); Volatile Compounds

\section{INTRODUCTION}

Nitrate and nitrite are inevitable additives in cured meat products due to antioxidant and antimicrobial properties as well as the formation of color and flavor. Some chemical and biochemical reactions occurring between degradation products of nitrite and the degradation products of protein, fat and carbohydrate play a significant role in the development of flavor of cured meat products [1]. It has been also shown that nitrate and nitrite are effective in formation and levels of volatile compounds [2].

The history of the meat curing is unclear but many sources indicate contamination of salt with potassium nitrate, which gives red color to meat, [3] was involved at the outset. Legal regulations have been made for these additives due to their health risks. Special directives in European Directive 2011/1129/EC (Section 8.2.4) [4] have been defined for the use of nitrate and nitrite in traditional cured meat products.

Nitrate may be used alone or with nitrite in curing process of meat products. While nitrite 
is used alone [5] or with nitrate in North America, Europe and many other countries in curing of meat products [6], in Mediterranean countries, use of nitrate has been preferred over a long time in ripened products [2]. Nitrate and nitrite were also used together in some dry-cured ham types [1,7].

Pastirma is a traditional Turkish raw-cured meat product produced by curing, drying and pressing of whole muscle obtained from certain parts of beef and water buffalo carcasses and by covering the meat with çemen after these processes. Sixteen or more pastirma-appropriate meat pieces can be obtained from one carcass. Different types of pastırma, which are named as to where muscle and muscle groups used as raw material are obtained (such as kuşgömü, kürek, sirt, etc.), are produced. The production of pastırma takes about one month according to the size of muscles used and processes conditions. It is categorized as an intermediate moisture food, and the production does not include heating or smoking processes. After final drying, pastırma is consumed as raw (without cooking). This product can be also stored for nine months without refrigeration [8]. Curing process is one of the most important stages in the production of pastirma. Nitrate is usually used as curing agent in production of pastırma. The ratio of nitrate used in pastırma production ranges from 750 ppm [9] to $1,000 \mathrm{ppm}[8,10]$.

So far, there are no studies in literature on the effects of low nitrate ratios for pastırma. Moreover, there are none on the effects of different nitrate levels on volatile compounds. Therefore, the objective of the present study was to investigate the effects of different nitrate levels $(150,300,450$, and $600 \mathrm{ppm})$ on the changes in the composition of volatile compounds, and thiobarbituric acid reactive substances (TBARS) as an indicator of lipid oxidation, non-protein nitrogenous matter content as an indicator of proteolysis, color and residual nitrite in pastırma.

\section{MATERIALS AND METHODS}

\section{The production of pastirma}

M. Longissimus dorsi from beef carcasses were used in the production. M. Longissmus dorsi muscles (right and left parts) were cut across the centre into two pieces. In total, four pieces were obtained for production of pastırma. Production was carried out twice. One carcass was used for each experiment.

First, fat and connective tissue from the surface of meat were removed. Then, deep incisions were made on meat strips. After this, production stages were performed as given in Table 1. Four groups of pastirma were produced by using the curing mixtures: $100 \mathrm{~g} \mathrm{NaCl}, 0.3 \mathrm{~g}$ sucrose, and $150 \mathrm{ppm} \mathrm{KNO}_{3}$ or $300 \mathrm{ppm} \mathrm{KNO}_{3}$ or $450 \mathrm{ppm} \mathrm{KNO}_{3}$ or $600 \mathrm{ppm} \mathrm{KNO}_{3}$ for $1 \mathrm{~kg}$ meat.

\section{Determination of $\mathrm{pH}$ and $\mathrm{a}_{\mathrm{w}}$ values}

Ten grams of sample were homogenized with $100 \mathrm{~mL}$ distilled water $(1: 10 \mathrm{w} / \mathrm{v})$, and $\mathrm{pH}$ value was measured using a $\mathrm{pH}$ meter. Water activity $\left(\mathrm{a}_{\mathrm{w}}\right)$ was determined by using a TH-500 $\mathrm{a}_{\mathrm{w}}$ Sprint
Table 1. The stages of pastirma production

\begin{tabular}{|c|c|c|c|}
\hline Production stage & Time & $\begin{array}{c}\text { Temperature } \\
\left({ }^{\circ} \mathrm{C}\right)\end{array}$ & $\begin{array}{c}\text { Relative } \\
\text { humidity (\%) }\end{array}$ \\
\hline Curing & $2 d$ & $4 \pm 1$ & - \\
\hline First drying & $6 d$ & $15 \pm 1$ & $80 \pm 2$ \\
\hline First pressing ${ }^{1)}$ & $20 \mathrm{~h}$ & $7 \pm 1$ & - \\
\hline Second drying & $6 d$ & $20 \pm 1$ & $70 \pm 2$ \\
\hline Second pressing ${ }^{2)}$ & $7 \mathrm{~h}$ & $25 \pm 1$ & - \\
\hline Third drying & $4 d$ & $20 \pm 1$ & $70 \pm 2$ \\
\hline Çemen coating & $1 d$ & $4 \pm 1$ & - \\
\hline Drying with çemen ${ }^{2)}$ & $8 d$ & $20 \pm 1$ & $70 \pm 2$ \\
\hline
\end{tabular}

1) For 1 kg meat, $15 \mathrm{~kg}$ weight.

${ }^{2)}$ Çemen was made from flour ground from fenugreek (Trigolella foenum graecum), mashed fresh garlic and red pepper.

(Novasina, Pfäffikon, Switzerland).

\section{Residual nitrite analysis}

In residual nitrite analysis of pastırma samples, the method given by Tauchmann [11] was used. Residual nitrite amount of samples was determined as $\mathrm{NaNO}_{2}$ ppm units based on coefficient and absorbance values which were calculated using sample weight, dilution factor and standard curve.

\section{Thiobarbituric acid reactive substances and non-protein} nitrogenous matter analyses

The TBARS values of samples were determined according to the method of Lemon [12] and were given as $\mu$ mol malondialdehyde/ $\mathrm{kg}$. Non-protein nitrogenous matter (NPN-M) content was determined according to Anonymous [13]. The results were expressed as $\mathrm{g} / 100 \mathrm{~g}$ of samples.

\section{Determination of color value}

Cross-sectional color values $\left(\mathrm{L}^{*}, \mathrm{a}^{*}\right.$, and $\left.\mathrm{b}^{*}\right)$ of samples were measured using a colorimeter (CR-200, Minolta Co, Osaka, Japan). Color value measurements were carried out according to the criteria defined by Commission Internationale de I'E Clairage based on three-dimensional color measurement. Analysis was performed on sliced samples as three replicates.

\section{Volatile compounds analysis}

The extraction of volatile compounds was done using a CAR/ PDMS (Supelco $75 \mu \mathrm{m}$, Bellefonte, PA, USA) fibre according to Kaban [8]. After the extraction, the compounds adsorbed by fibre were desorbed from the injection port of the gas chromatography (Agilent Technologies 6890N, Santa Clara, CA, USA) for 6 min at $250^{\circ} \mathrm{C}$, and the compounds were determined by a mass selective detector (Agilent 5973, USA). Volatile compounds were separated in a DB-624 (Agilent J\&W Scientific, Santa Clara, CA, USA; $60 \mathrm{~m}, 0.25 \mathrm{~mm}$ i.d., $1.4 \mu \mathrm{m}$ film) capillary column. Helium was used as carrier gas. The temperature programme was started when the fibre was inserted and held at $40^{\circ} \mathrm{C}$ for $6 \mathrm{~min}$ and subsequently programmed from $40^{\circ} \mathrm{C}$ to $110^{\circ} \mathrm{C}$ at $3^{\circ} \mathrm{C} / \mathrm{min}$ and at 
a rate of $4^{\circ} \mathrm{C} / \mathrm{min}$ to $150^{\circ} \mathrm{C}$, then, at a rate of $10^{\circ} \mathrm{C} / \mathrm{min}$ to $210^{\circ} \mathrm{C}$ where it was held for another $12 \mathrm{~min}$. The gas chromatography/ mass spectrometry (GC-MS) interface was maintained at $280^{\circ} \mathrm{C}$. Mass spectra were obtained by electron impact at $70 \mathrm{eV}$, and data were acquired across the range 30 to $400 \mathrm{amu}$. The results were evaluated by comparing with mass spectra from a database developed by the National Institute of Standards and Technology (NIST) and WILEY, or standard molecules (for calculating kovats indices, Supelco 44585-U, Bellefonte, PA, USA) and by matching their retention indices with those in the literature. Each sample was analysed as three replicates.

\section{Statistical analysis}

In the study, nitrate level $\left(150,300,450\right.$, and 600 ppm $\left.\mathrm{KNO}_{3}\right)$ was taken as factor. The experiments were carried out according to randomized complete block design as two replicates. The data was tested by variance analysis and differences between means were evaluated by Duncan's multiple range tests using SPSS 20 statistics software (Armonk, NY, USA, 2011). The relationship between the various nitrate levels and volatile compounds detected with solid phase microextraction (SPME) GC/MS analysis was evaluated by principal component analysis (PCA) using Unscrambler v.10.01 (Camo Process AS., Oslo, Norway).

\section{RESULTS AND DISCUSSION}

$\mathrm{pH}$ and $\mathrm{a}_{\mathrm{w}}$

Nitrate level had significant effect $(\mathrm{p}<0.05)$ on $\mathrm{pH}$ value of pastırma samples. While the lowest mean $\mathrm{pH}$ value was determined in the group containing $150 \mathrm{ppm}$ nitrate, $\mathrm{pH}$ value increased with increasing of nitrate ratio, and the highest mean $\mathrm{pH}$ value was found in the group with added $600 \mathrm{ppm}$ nitrate $(\mathrm{p}<0.05)$ (Table 2$)$. The $\mathrm{pH}$ value was found above 5.5 in all of groups. This finding was in agreement with the results of other researchers $[8,10]$. The highest $\mathrm{pH}$ value of pastırma should be 6.0 according to the Turkish Food Codex Communiqué on Meat and Meat Products [14].

Nitrate level had no statistically significant effect on $\mathrm{a}_{\mathrm{w}}$ value ( $p>0.05)$. Water activity values were determined below 0.90 in all groups, and the $\mathrm{a}_{\mathrm{w}}$ value ranged from 0.841 to 0.863 (Table 2). In pastırma, water activity values are affected by the salt concentration and drying processes. Therefore, pastirma belongs to the group of intermediate moisture food $[15,16]$. Water activity shows a decrease depending on the progress of production time [8]. In pastirma, water activity is the most important hurdle factor for microbiological stability, it is stated that it should be below $0.90[8,15]$.

\section{Residual nitrite}

Nitrate and nitrite are important additives in pastırma production in terms of color formation, ensuring of curing flavor, prevention of rancidity and antimicrobial activity. However, reduction of nitrate to nitrite is necessary in the processes using nitrate for formation of these effects [1]. In the reduction of nitrate to nitrite, microorganisms having nitrate reductase activity play an important role. On the other hand, the residual nitrate and nitrite must be under certain values in the final product because of negative effects on human health.

Nitrate level had no statistically significant effect on residual nitrite amounts of pastırma samples produced with different nitrate levels ( $\mathrm{p}>0.05$ ), and amount of residual nitrite varied from 3.35 to $15.05 \mathrm{ppm}$ (Table 2). According to this result, residual nitrite amount was less than 50 ppm given as the limit value [17], even if $600 \mathrm{ppm}$ nitrate was used. In another study about cured dried whole processed meat products, residual amount of nitrite was determined as $16.8 \mathrm{ppm}$ [18].

\section{Thiobarbituric acid reactive substances and non-protein nitrogenous matter values}

Nitrate level had a significant effect on TBARS value of pastırma $(\mathrm{p}<0.01)$. The highest TBARS value was determined in the group produced using $450 \mathrm{ppm} \mathrm{KNO}_{3}(\mathrm{p}<0.05)$. Statistically, there were not any differences between $300 \mathrm{ppm}$ and $600 \mathrm{ppm}$ potasium nitrate levels ( $p>0.05$ ) (Table 2). The lowest TBARS value was found in the group containing $150 \mathrm{ppm} \mathrm{KNO}_{3}$ and this value was statistically different from mean TBARS values of other groups $(\mathrm{p}<0.05)$. Thiobarbituric acid reactive substances, secondary products of lipid oxidation are used as indicators of lipid oxidation. Kaban [8] reported that lipid oxidation continues during the production of pastirma and as a result of that, TBARS value increases.

In dry-cured meat products, proteolysis is one of the most important reactions. Amounts of non-protein nitrogenous substances such as peptides and free amino acids increase as a result of proteolysis. It was determined that non-protein nitrogenous

Table 2. Overall effect of nitrate level on physico-chemical properties of pastirma (values are means \pm SD)

\begin{tabular}{|c|c|c|c|c|c|c|c|c|}
\hline $\begin{array}{l}\text { Nitrat levels } \\
\text { (ppm) }\end{array}$ & $\mathrm{pH}$ & $a_{w}$ & $\begin{array}{c}\text { TBARS } \\
(\mu \mathrm{mol} \text { MDA } / \mathrm{kg})\end{array}$ & $\begin{array}{l}\text { Residual nitrite } \\
\text { (mg/kg) }\end{array}$ & $\begin{array}{c}\text { NPN-M } \\
(\mathrm{g} / 100 \mathrm{~g})\end{array}$ & $\mathrm{L}^{*}$ & $a^{*}$ & $b^{*}$ \\
\hline 150 & $5.62 \pm 0.01^{a}$ & $0.853 \pm 0.02^{a}$ & $21.26 \pm 1.59^{a}$ & $9.19 \pm 2.38^{a}$ & $4.32 \pm 0.76^{a}$ & $32.23 \pm 1.73^{\mathrm{a}}$ & $11.68 \pm 1.18^{a}$ & $4.50 \pm 1.53^{a}$ \\
\hline 300 & $5.66 \pm 0.01^{a b}$ & $0.841 \pm 0.03^{\mathrm{a}}$ & $30.49 \pm 1.82^{b}$ & $3.35 \pm 1.63^{\mathrm{a}}$ & $4.49 \pm 0.15^{a}$ & $31.06 \pm 1.12^{\mathrm{a}}$ & $12.98 \pm 1.92^{\mathrm{a}}$ & $3.02 \pm 1.57^{a}$ \\
\hline 450 & $5.69 \pm 0.03^{b}$ & $0.847 \pm 0.02^{a}$ & $37.52 \pm 0.75^{c}$ & $15.05 \pm 7.28^{a}$ & $4.64 \pm 0.06^{a}$ & $34.34 \pm 1.11^{\mathrm{a}}$ & $13.47 \pm 3.22^{\mathrm{a}}$ & $2.90 \pm 1.97^{a}$ \\
\hline 600 & $5.70 \pm 0.01^{b}$ & $0.863 \pm 0.00^{\mathrm{a}}$ & $32.06 \pm 0.98^{b}$ & $10.58 \pm 0.04^{a}$ & $4.65 \pm 0.14^{a}$ & $34.37 \pm 3.12^{\mathrm{a}}$ & $14.06 \pm 1.12^{\mathrm{a}}$ & $3.20 \pm 1.84^{a}$ \\
\hline
\end{tabular}

SD, standard deviation; $a_{w}$, water activity; TBARS, thiobarbituric acid reactive substances; MDA, malondialdehyde; NPN-M, non-protein nitrogenous matter

${ }^{a-c}$ Any two means in the same column having the same letters in the same section are not significantly different at $p>0.05$. 
matter content as an indicator of proteolysis increase during pastırma production process [8]. In the present study, non-protein nitrogenous matter content varied from 4.32 to $4.69 \mathrm{~g} / 100 \mathrm{~g}$ in samples (Table 2). However, there were no statistical differences among groups in terms of non-protein nitrogenous matter content $(\mathrm{p}<0.05)$.

\section{Color values}

The factors such as the use of curing agent (nitrate, nitrite, and nitrate/nitrite), $\mathrm{pH}$ value and myoglobin content of raw material and manufacturing process are effective in color formation of cured meat products $[1,19]$. Nitrate is the most important curing agent used in the production of pastırma $[8,10]$. This curing agent, which is generally used as potassium nitrate, can usually be added to salt in various amounts before the production. Nitrate level had no significant effect on $\mathrm{L}^{*}, \mathrm{a}^{*}$, and $\mathrm{b}^{*}$ values of pastırma samples ( $>0.05$ ) (Table 2). According to these result, use of $150 \mathrm{ppm}$ nitrate in pastırma production was sufficient for color formation.

\section{Volatile compounds}

Many volatile compounds belonging to various chemical groups occur as a result of many reactions during pastirma production $[1,8,16]$. A total of 46 compounds consisting of 11 different chemical such as aliphatic hydrocarbons, sulfur compounds, aromatic hydrocarbons, aldehydes, terpenes, ketones, esters, furans, acids, alcohols, and nitrogen compounds were identified in pastırma samples produced using different nitrate levels (Table 3).

From 11 aldehydes identified, nitrate level had a significant effect on the 2-pentanal, hexanal, heptanal, octanal, and propanal2-methyl-3-phenyl at levels of $\mathrm{p}<0.05$ or $\mathrm{p}<0.01$. 2-Methyl-3phenyl propanal from statistically significant aldehydes showed the highest value at $150 \mathrm{ppm}$ level (Table 3). Aldehydes have an important share in volatile profile of pastirma [8,16]. In a market research conducted by Kaban and Kaya [16], it was reported that total peak area of aldehydes ranged from 17.21 to 43.80 , and hexenal was dominant compound.

3-Methyl thiopene, 10 sulphur compounds identified from pastırma samples, was only found significantly at $\mathrm{p}<0.05$ level (Table 3). Sulphur compounds have been found in the other studies conducted on pastırma $[8,16]$. In pastırma, sulphur compounds were concluded to be resulting from çemen used in final stage [8]. Garlic also found in the composition of çemen has been shown as source of many sulphur compounds by Ramirez and Cava [20].

Three ketones as 1,3-pentadiene, 6-methyl-5-hepten-2-one, and 3,5-octadien-2-one were determined in pastırma samples (Table 3). None of these compounds were statistically significant $(\mathrm{p}>0.05)$. Similarly, it was also determined that numbers and percentage values of ketones are low in studies of volatile compounds on pastirma $[8,16]$. Kaban [8] reported that ketones were not found in raw material used in pastırma production, but ketones were generated during the production.
In pastırma samples, six different aromatic hydrocarbons; toluene, benzene- 2-methyl-1-propenyl, benzene-1-methoxy4-(1-propenyl), 1-methylene-1H-Indene, benzene-1,3-bis (1,1dimethylethyl), and benzene-1,2-dimethoxy-4-(2-propenyl), were determined (Table 3). The sources of aromatic hydrocarbons can show differences considerably. Of these compounds, toluen can come from lipid degradation as well as animal feeds [21]. On the other hand, Marco et al [22] reported that this compound may also occur as a result of amino acid catabolism. As can be understood from the average toluen levels that was found statistically significant, when nitrate level increased, toluen amount decreased, and this compound was not observed at 600 ppm level. Kaban [8] also determined that toluen in the final product was not found.

Aliphatic hydrocarbons are compounds that have a limited effect on aroma of dry-cured meat products due to having high threshold values [20]. In the present study, two different aliphatic hydrocarbons; hexane and tridecane, were identified. Nitrate level had a significant effect on both of them $(\mathrm{p}<0.05)$. Aliphatic hydrocarbons, secondary products of lipid oxidation, were determined at different levels in other studies related to pastirma $[8,16]$. A decrease in the amounts of these compounds was observed depending on increasing of nitrate level.

Esters occur usually as a result of esterification of carboxylic acids and alcohols in meat products. Low molecular weight esters such as ethyl ester, may be come from carbohydrate metabolism [23]. On the other hand, Olesen et al [24] reported that ethyl acetate level in fermented meat products produced by using nitrate was higher than the samples produced by using nitrite. In the present study, nitrate level showed significant effects on butyl propionate ( $\mathrm{p}<0.05), 2,4$-Hexadienoic acid methyl ester and propyl hexanoate $(\mathrm{p}<0.01)$ at different significance levels. Level of other esters determined except 2,4-hexadienoic acid methyl ester decreased with increasing nitrate levels. The highest level of 2,4-hexadienoic acid methyl ester was determined in pastirma samples containing $300 \mathrm{ppm}$ nitrate. In esters, as in aromatic and aliphatic hydrocarbons, the decrease was usually observed with increasing level of nitrate.

Terpenes are generally considered to be sourced off spices, especially from pepper [25]. However, it was also indicated that some terpenes were found in meat as a result of their existence in animal feed [26]. In a study on pastırma, five terpenes including $\alpha$-pinene, $\beta$-pinene, 3-carene, $\mathrm{D}$-limonene and o-cymol were determined in raw materials and it was concluded that terpenes were related to animal feed [8]. In this study, five terpenes were identified as $\beta$-myrcene, $\mathrm{D}$-limonene, linalool, eugenol, and caryophyllene (Table 3). The levels of $\beta$-myrcene $(p<0.05)$ and $D$ limonene $(\mathrm{p}<0.01)$ compounds found statistically significantly decreased depending on increasing nitrate level and even could not be determined at the level of $600 \mathrm{ppm}$ nitrate.

In pastirma samples produced with different levels of nitrate, the nitrate level showed statistically significant effect on 1-methyl$1 \mathrm{H}$-pyrrole $(\mathrm{p}<0.05)$. Soto et al [27] also determined this compound 
Table 3. Volatile compounds of pastırma samples produced by using different nitrate levels (values are means \pm SD)

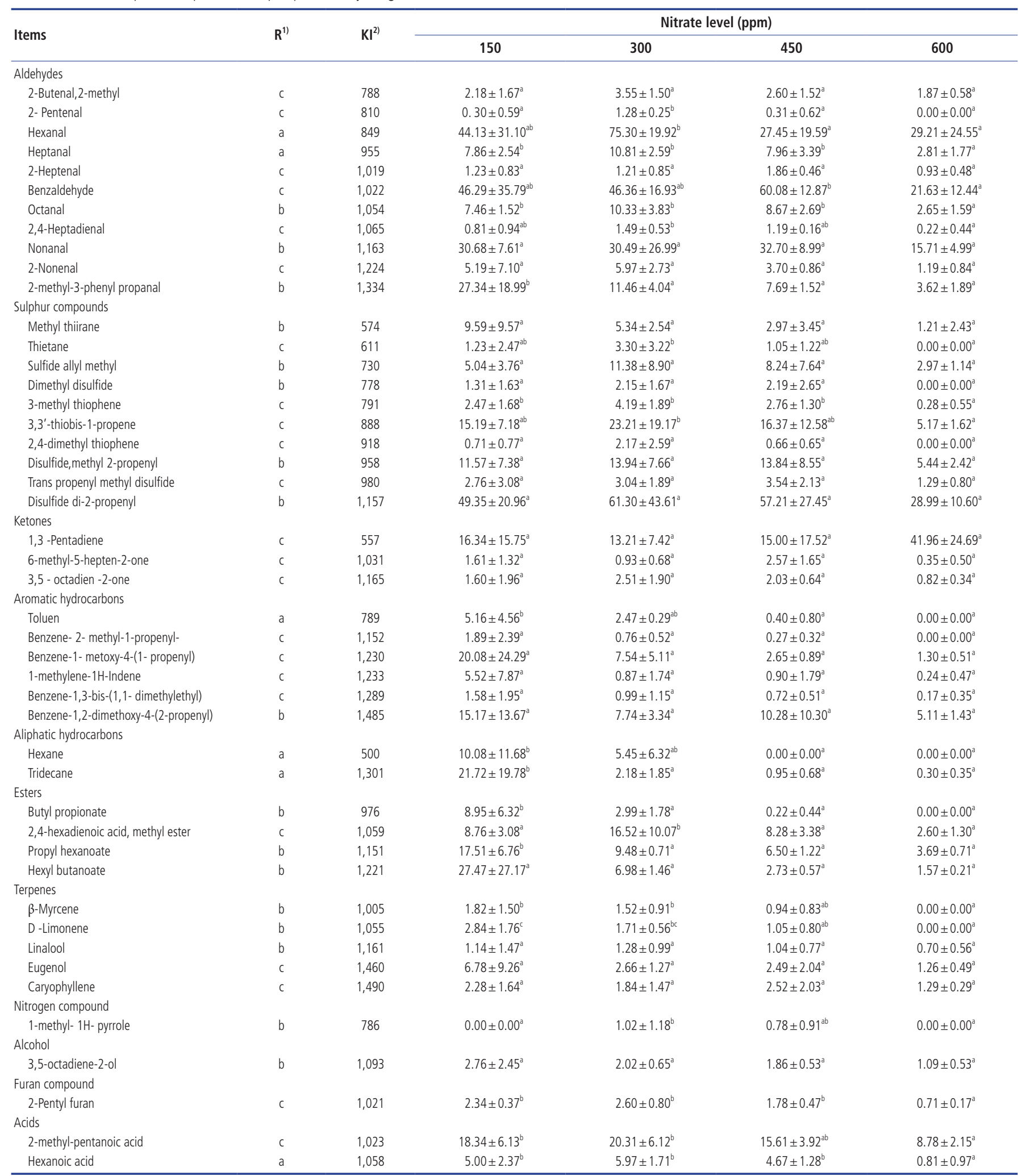

Results are expressed in Arbitrary Area Units $\left(\times 10^{-6}\right)$ as means of 3 replicates of each pastırma.

${ }^{1)} R$, reliability of identification: a, mass spectrum and retention time identical with an authentic sample; $b$, mass spectrum and Kovats index from literature in accordance; $c$, tentative identification by mass spectrum.

${ }^{2)} \mathrm{KI}$ : Kovats index calculated for DB-624 capillary column (J\&W Scientific, $60 \mathrm{~m}, 0.25 \mathrm{~mm}$ i.d., $1.4 \mu \mathrm{m}$ film) installed on a gas chromatograph equipped with a mass selective detector.

$a, b$ Any two means in the same row having the same letters are not significantly different at $p>0.05$. 
in dry cured loin. Only one alcohol (3,5-octadiene-2-ol) was determined in pastırma produced using different levels of nitrate. However, nitrate level had no significant effect on 3,5-octadiene2 -ol ( $p>0.05)$. Five different alcohols in the production of pastirma were detected by Kaban [8]. Alcohols are significant aroma compounds in dry fermented meat products because of low odor threshold, and their most important sources are lipid oxidation, carbohydrate metabolism and amino acid catabolism [28].

2-Pentyl-furan identified in this study was also been determined in a previous study on pastırma by Kaban [8]. This compound was affected very significantly $(\mathrm{p}<0.01)$ from nitrate level and its level decreased as nitrate level increased. Additionally, this compound was also determined in raw-cured whole processed meat products such as cured loin [7], Iberian ham [29], dry cured ham [30]. It was known that this compound occurs during the heat treatment, also might occur as a result of the oxidation of linoleic acid [29].

In pastırma samples, pentanoic acid, 2-methyl and hexanoic acid as acids were found (Table 3). In this research, nitrate level, the main cause of variation, had significant effect at on 2-methylpentanoic acid $(p<0.05)$ and on hexanoic acid $(p<0.01)$. The lowest average level of hexanoic acid and pentanoic acid, 2-methyl was determined in the group containing $600 \mathrm{ppm}$ nitrate. In a study carried out on pastırma, Kaban and Kaya [16] identified two different acids as butanoic acid, 3-methyl, and hexanoic acid.

PCA was applied to study the relationships between nitrate level and volatile compounds of pastırma. Two principal components explained $81 \%$ of the total variance. The first component explained $57 \%$ of the variation in measured properties and the second component $24 \%$ of the variation. Figure 1 shows a Biplot with principal component 1 (PC1) plotted against principal component 2 (PC2). The biplot obtained from this analysis showed that all of the volatile compounds evaluated except 1,3-pentadiene were highly related with PC1 (Figure 1). PC1 differentiated the $600 \mathrm{ppm}$ nitrate group showing a negative correlation from the groups containing 150, 300, and $450 \mathrm{ppm}$ nitrate. The 300,450 , and $600 \mathrm{ppm}$ nitrate groups were placed on the positive axis of PC2, however, $150 \mathrm{ppm}$ nitrate group showed only negative correlation with PC2.

\section{CONCLUSION}

Potassium nitrate is used extensively as a curing agent in the production of pastırma. Residual nitrite level was found much lower than $50 \mathrm{ppm}$ even in the pastırma produced with $600 \mathrm{ppm}$ nitrate. In addition, a negative effect in terms of pastirma's color was not observed in the group treated with $150 \mathrm{ppm}$ nitrate. In all groups with different levels of nitrate, $\mathrm{pH}$ and aw values were determined above 5.5 and under the 0.90 , respectively. NPN-M content value was not affected by the use of different levels of nitrate, while some differences may be observed in TBARS value. Decreases were found in the levels of aldehydes, a significant share inside of volatile compounds, as well as aromatic hydrocarbons, esters and terpenes with increasing of nitrate level.

\section{CONFLICT OF INTEREST}

We certify that there is no conflict of interest with any financial organization regarding the material discussed in the manuscript.

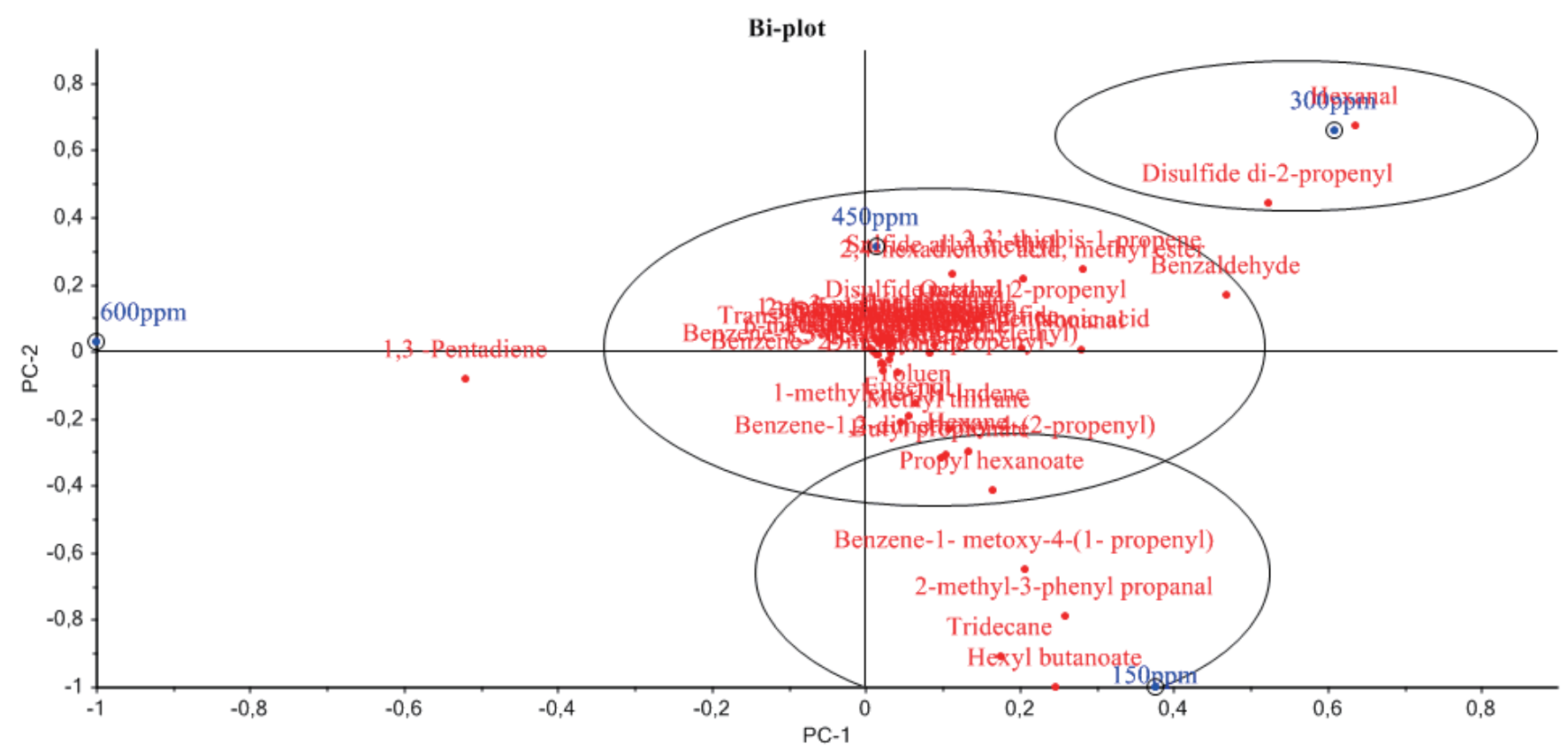

Figure 1. Principal component analysis of the volatile compounds of pastırma produced with different nitrate levels. Principal component1 (PC-1); principal component 2 (PC-2). 


\section{ACKNOWLEDGMENTS}

This study has been supported by the Research Council of Atatürk University (BAP 2012/257). The financial support of Atatürk University is gratefully acknowledged.

\section{REFERENCES}

1. Kaya M, Kaban G. Fermented meat products. In: Aran N, editor. Food biotechnology. İstanbul: Nobel Yayınc1lık; 2010. p. 157-90.

2. Flores J. Mediterranean vs northern European meat products. Processing technologies and main differences. Food Chem 1997;59:505-10.

3. Sebranek JG, Bacus JN. Cured meat products without direct addition of nitrate or nitrite: what are the issues? Meat Sci 2007;77:136-47.

4. European Commission. Commission Regulation (EU) no 1129/2011 of 11 November 2011 amending Annex II to Regulation (EC) no 1333/2008 of the European Parliament and of the Council by establishing a Union list of food additives. Official Journal of the European Union, L295; 2011. p. 1-177.

5. Lammers M, Dietze K, Ternes W. Headspace volatiles of dry-cured ham: a comparison of different manufacturing styles by SPME and GC/MS analysis. J Food Proc Preserv 2011;35:850-60.

6. Sen NP, Baddoo PA. Trends in the levels of residual nitrite in Canadian cured meat products over the past 25 years. J Agric Food Chem 1997; 45:4714-8.

7. Muriel E, Antequera T, Petron MJ, Andres AI, Ruiz J. Volatile compounds in Iberian dry-cured loin. Meat Sci 2004;68:391-400.

8. Kaban G. Changes in the composition of volatile compounds and in microbiological and physicochemical parameters during pastırma processing. Meat Sci 2009;82:17-23.

9. Aktaş N, Aksu MI, Kaya M. Changes in myofibrillar proteins during processing of pastirma (Turkish dry meat product) produced with commercial starter cultures. Food Chem 2005;90:649-54.

10. Doğruer Y, Güner A, Gürbüz Ü, Uçar G. The effect of sodium and potassium nitrate on the quality of pastırma during the production process. Turk J Vet Anim Sci 2003;27:805-11.

11. Tauchmann F. Methods of chemical analysis of meat and meat products. Bundensanstalt für Fleischforschung, Kulmbach; 1987.

12. Lemon DW. An improved TBA test for rancidity new series circular, No:51. Halifax, NS, Canada: Halifax-Laboratory; 1975.

13. Anonymous. Official collection of investigation procedures according to $35 \mathrm{LMBG}$. Analysis of food. Determination of non-protein nitrogen substances in meat products; 1989.

14. Anonymous. Turkish food codex communiqué on meat and meat products. Ankara, Turkey: Communiqué no: 2012/74. Number: $28488 ; 2012$.

15. Leistner L. Hurdle technology in meat products and other foods.
Quality of food science and technology. In: Stufe R, editor. Scientific Workshop 25th Years Institute for Research and Development of the Maizena GmbH. Heilbronn, 2-4 March; 1988. p. 323-340.

16. Kaban G, Kaya M. Volatile compounds of traditionally produced pastırma. Fleischwirtsch 2011;91:112-6.

17. Anonymous. The standard of pastırma. Pastırma. TS No: 1071/Şubat 2002. Ankara, Turkey: The Institute of Turkish Standardization; 2002.

18. Müller WD. Curing and smoking. Earlier or today healthier? In Importance of meat and sausage in the human nutrition. Kulmbach, Germany: Bundesaanstalt für Fleischforschung, Kulmbacher Reihe Band 9; 1989.

19. Adamsen CE, Møller JKS, Laursen K, Olsen K, Skibsted LH. Znporphyrin formation in cured meat products: Effect of added salt and nitrite. Meat Sci 2006;72:672-9.

20. Ramirez R, Cava R. Volatile profiles of dry-cured meat products from three different Iberian $\times$ duroc genotypes. J Agric Food Chem 2007;55:1923-31.

21. Berdagué JL, Monteil P, Montel MC, Talon R. Effects of starter cultures on the formation of flavour compounds in dry sausage. Meat Sci 1993;35:275-87.

22. Marco A, Navarro JL, Flores M. The sensory quality of dry fermented sausages as affected by fermentation stage and curing agents. Euro Food Res Technnol 2008;26:449-58.

23. Rotsatchakul P, Chaiseri S, Cadwallader KR. Identification of characteristic aroma components of Thai fried chili paste. J Agric Food Chem 2008;56:528-36.

24. Olesen PT, Meyer AS, Stahnke LH. Generation of flavour compounds in fermented sausage the influence of curing ingredients, Staphylococcus starter culture and ripening time. Meat Sci 2004;66:675-87.

25. Hinrichsen L, Pedersen SB. Relationship among flavor, volatile compounds, chemical changes, and microflora in Italian-type dry-cured ham during processing. J Agric Food Chem 1995;43:2932-40.

26. Ansorena D, Gimeno O, Astiasaran I, Bello J. Analysis of volatile compounds by GC-MS of a dry fermented sausage: Chorizo De Pamplona. Food Res Int 2001;34:67-75.

27. Soto E, Hoz L, Ordóñez JA, et al. Impact of feeding and rearing systems of Iberian pigs on volatile profile and sensory characteristics of drycured loin. Meat Sci 2008;79:666-76.

28. Mateo J, Zumalacarregui JM. Volatile compounds in chorizo and their changes during ripening. Meat Sci 1996;44:255-73.

29. Ruiz J, Ventanas J, Cava R, Andres A, Garcia C. Volatile compounds of dry-cured Iberian ham as affected by the length of the curing process. Meat Sci 1999;52:19-27.

30. Flores M, Gianelli MP, Pe'Rez-Juan M, Toldra F. Headspace concentration of selected dry-cured aroma compounds in model systems as affected by curing agents. Food Chem 2007;102:488-93. 